\title{
DETERGENT WASTE CONDUCTIVITY IN PRODUCING ELECTRICITY
}

\author{
Asti Riani Putri \\ Information Technology Education \\ Department \\ STKIP PGRI Tulungagung \\ Tulungagung \\ East Java, Indonesia \\ asti@stkippgritulungagung.ac.id
}

\author{
Anggara Sukma Ardiyanta \\ Information Technology Education \\ Department \\ STKIP PGRI Tulungagung \\ Tulungagung \\ East Java, Indonesia \\ anggara@stkippgritulungagung.ac.id
}

\author{
Anang makruf \\ Information Technology Education \\ Department \\ STKIP PGRI Tulungagung \\ Tulungagung \\ East Java, Indonesia \\ anangmarub65@gmail.com
}

\begin{abstract}
The importance of socialization about alternative energy that can be used for daily needs, for example from the simplest such as lighting at home, although not permanent but is very useful in the event of a sudden power outage. The high price of electricity makes small communities have to think twice as much to regulate daily expenditure needs so as to encourage to find alternative energy that can produce electricity that is environmentally friendly. Seeing the large number of detergent products in Indonesia, it inspires to process the waste from laundry clothes or other objects and even the detergent water itself, because so far the used laundry waste is thrown away so that it can pollute the environment. The purpose of this study is to reduce the effect of environmental pollution due to used laundry waste which is used as an alternative energy source to turn on lighting lamps at home or even on the road. The method used in this research is a chemical or electrolysis reaction involving zinc and carbon as well as the content in detergent washing water. From several experiments conducted for 3 detergents with several parameters, namely the amount of mass and water volume of $120 \mathrm{ml}$. From the experiment the voltage is 1 volt with a current of $2 \mathrm{~mA}$ for detergent Rinso, for DAIA detergent the voltage is 0.7 and current is $0.56 \mathrm{~mA}$, and the experiments tested on SOKLIN produce a voltage of 0.8 volt and a current of $1 \mathrm{~mA}$. Whereas the testing which was carried out randomly with a volume of $1200 \mathrm{ml}$ water produced a voltage of $0.547 \mathrm{v}$ with a large current of $0.006 \mathrm{~mA}$. This proves that detergent waste can be utilized as a renewable energy although it still requires further research but this can ease the burden on the community to pay for electricity from PLN and in the subsequent development independent power plants are built in each house so that the community can save on electricity.
\end{abstract}

Keywords-Alternative Energy, electricity, detergent (key words)

\section{INTRODUCTION}

At present many industrial factories produce various kinds of products like soap and detergents. Soap and detergents are important because they are frequently utilized in day to day activities of people. They are used in bathing, washing hands and clothes [10]. Especially detergent products, detergents are included in products that can produce waste, and the waste that can affect natural resources and the environment, for example natural damage due to pollution of water, soil, and air. Waste produced by detergents themselves is classified as residual waste.

Today most Indonesian people wash clothes using detergent, so if the waste from the former detergent is discarded carelessly without any special treatment, it will further damage the environment and existing natural resources. For example, if the soil is polluted, trees or plants will not be able to live because it has been mixed with chemicals contained in detergents, and if the trees and plants are no longer able to grow, oxygen $(\mathrm{O} 2)$ in nature will reduced because there is no photosynthesis and will cause respiratory problems for humans.

In fact, the Indonesian people dispose of washing wastewater directly to the ground without going through a screening process first, if this continues to occur, the washing wastewater can seep into the ground. Ground water which is the main source of water in our lives will be polluted by surfactants, the presence of surfactants in the environment has caused scientific and regulatory concern and as a consequence, toxicity data have been determined since the early 1950s for several surfactants and various species of freshwater and marine life [9]. Through the electrolysis process, applying the appropriate voltage will break the attractive forces between these two opposing charges. Products that occur in the form of charged atoms which are then called ions [1].

We know that detergent waste is waste that has not been treated properly The increasing environmental pollution arising from detergent use is becoming a growing concern. Lack of information on the effects of detergent on living organisms makes people to handle or dispose detergents carelessly [11]. In connection with these problems to cope with more and more detergent waste and damage the environment and natural resources, we through this paper want to provide a solution that is "Making Indonesia Save Energy by Changing Detergent Water Waste into Renewable Energy". Besides being able to reduce waste, it is also useful for saving energy needs from fossils.

\section{LITERATURE REVIEW}

\section{A. Detergent Waste}

Water is a compound that is important for all life forms that are known to date on Earth. Water covers nearly $71 \%$ of the Earth's surface and there are 1.4 trillion cubic kilometers available on Earth. However, some of the surface water is contaminated with waste.

Waste is waste generated from a production process both industrial and domestic (household). Where people settled, there the various types of waste will be generated. There is garbage, there is toilet water (black water), and there is greywater, greywater is defined as the generated wastewater from household activities, which include bathroom, showers, laundry, and kitchen but not black water from the toilet [7]. One of the routine activities carried out at home is washing clothes using detergent. 
Detergent is a mixture of various materials, which are used to help cleanse and are made from petroleum-derived ingredients. Compared to soap, detergents have the advantages of having a better washing ability and are not affected by water hardness.

The ingredients contained in detergent are as follows:

- Surfactants (surface active agents) are surface active substances that have different ends, namely hydrophilic (like water) and hydrophobic (like fat). The material is a lowering of the surface tension of the water so it can release dirt that adheres to the surface of the material. Broadly speaking, there are four categories of surfactants namely:

a. Anionic : Alkyl Benzene Sulfonate, (ABS), Linier Alkyl Benzene Sulfonate, (LAS) Alpha Olein Sulfonate (AOS)

b. Cationic : Ammonium Salt

c. Nonionic : Nonylphenol polyethoxyle

d. Amphoteric : Acyl Ethylenediamines

- Builder to increase washing savings from surfactants by deactivating minerals that cause water hardness.
a. Phosphate : Sodium Tri Poly Phosphate (STPP)
b. Acetate : Nitril Tri Acetate (NTA), Ethylene Diamine Tetra Acetate (EDTA)
c. Silicate : Zeolit
d. Citric : Citric Acid

- A filler is a detergent additive, only adding to the quantity. Example of Sodium Sulphate.

- Additives are supplements / additives only, for example fragrances, solvents, bleach, dyes, not directly related to the washing power of detergents. Additives are added more for the purpose of commercializing the product, for example: Enzyme, Borax, and Sodium Chloride Carboxyl Methyl Cellulose (CMC).

\section{B. Volta Cell}

Voltaic cells are electrochemical cells that can cause electric current due to a redox reaction in the cell. The oxidation reaction occurs at the anode which is the electrode $(-)$, while the reduction reaction occurs at the cathode which is the electrode $(+)$.

To understand the mechanism of voltaic cells, let's look at a classic example of voltaic cells consisting of $\mathrm{Zn}$ (zinc) and $\mathrm{Cu}$ (zinc) electrodes. $\mathrm{Zn}$ metal which is immersed in $\mathrm{ZnSO} 4$ solution (clear colorless) is an anode (where oxidation takes place), while copper metal immersed in $\mathrm{CuSO} 4$ solution (clear blue) is a cathode (where the reduction takes place) as shown in the figure 1 . The two solutions are connected by a "salt bridge". Each zinc and copper metal is connected to a voltmeter through a wire. Redox reactions that occur are as follows.

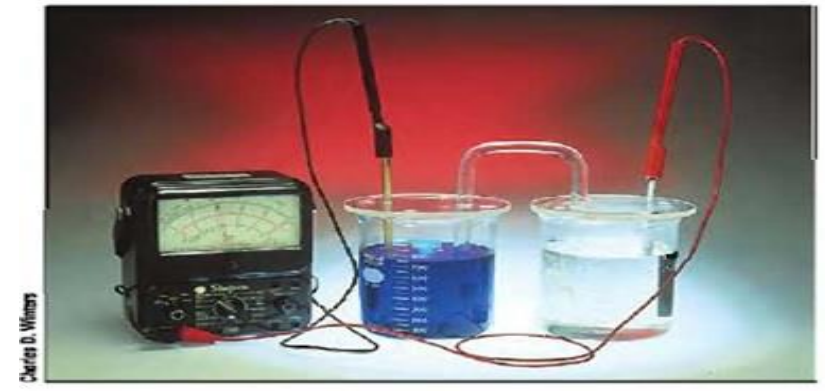

Zn metal will oxidize by reaction:

$$
\mathrm{Zn}_{(\mathrm{s})} \rightarrow \mathrm{Zn}^{2+}{ }_{(\mathrm{aq})}+2 \mathrm{e}^{-}
$$

Fig. 1. Volta Cell (Masterton. 2009. Hal 482)

The anode produced electrons will flow through the wire, so the anode is said to be a negative electrode. While in $\mathrm{ZnSO}_{4}$ solution has been decomposed to produce

$$
\mathrm{Zn}^{2+}{ }_{(\mathrm{aq})}+\mathrm{SO}_{4}^{2-}{ }_{(\mathrm{aq})}
$$

The formation of $\mathrm{Zn} 2+$ ions from oxidation results in the solution at the anode being excess positive ions and then the reduction reaction at the cathode. The $\mathrm{CuSO} 4$ solution at the cathode was initially decomposed as followings:

$$
\mathrm{Cu}^{2+}{ }_{(\mathrm{qq})}+\mathrm{SO}_{4}{ }^{2-}(\mathrm{aq}) .
$$

The anode produced electrons will pass through the voltmeter to the cathode through the $\mathrm{Cu}$ electrode and be captured by $\mathrm{Cu} 2+$ ions present in the solution so that a reaction occurs as followings:

$$
\mathrm{Cu}^{2+}{ }_{(\mathrm{aq})}+2 \mathrm{e}^{-} \rightarrow \mathrm{Cu}_{(\mathrm{s})}
$$

$\mathrm{Cu}$ deposits will stick to $\mathrm{Cu}$ electrodes. And the positive ion solution becomes reduced or the cathode becomes excess negative ions. The salt bridge containing $\mathrm{KNO} 3$ solution will decompose to produce $\mathrm{K}+(\mathrm{aq})+\mathrm{NO} 3-(\mathrm{aq})$. It functions to neutralize the excess positive ions at the anode by releasing NO3 ions - and neutralize the negative ions at the cathode by releasing $\mathrm{K}+$ ions. Therefore the electrons continue to flow continuously. This flow of electrons will produce an electric current in the opposite direction, where the anode is a negative pole and the cathode is a positive pole. If written cell notation is the following:

\section{$\mathrm{Zn} / \mathrm{Zn}^{2+} / / \mathrm{Cu}^{2+} / \mathrm{Cu}$}

The ability of the reduction reaction of an atom or ion is shown by the standard electrode potential value $\left(E_{o}\right)$. The higher the value of $E_{o}$ atoms the easier it is to experience a reduction reaction, and conversely the lower the value of $E_{o}$ the more difficult it is to experience a reduction reaction (easy to experience oxidation). The reaction takes place 
spontaneously, can flow electrons (electricity) if the electrode used as an anode is more easily oxidized than the cathode.

Making voltaic cells must consist of two electrodes and an electrolyte solution. The two electrodes act as positive electrodes and negative electrodes. Positive electrodes are made from materials that are easily subjected to oxidation reactions, usually in the form of $\mathrm{Zn}$ metals. While negative electrodes from materials that are easily subjected to a reduction reaction. If you use carbon (inert) electrodes, the ions in the solution must be easily reduced. From the description basically we can make voltaic cells from materials that are in the vicinity, or suitable used materials.

\section{Batteries from Detergent Waste}

The detergent battery we assembled uses $\mathrm{Zn}$ electrodes as an anode and carbon (C) as a cathode. The metal $\mathrm{Zn}$ (zinc) has an $E_{o}$ value $=-0.762 \mathrm{~V}$ so it is often chosen as anode because it has a low $E_{o}$ value which means it is easy to undergo an oxidation reaction. Electrical conductance is a measure of electrical conductivity, usually expressed in mhos. Since The solution we use is detergent waste which is still possible to use. Detergents contain a variety of electrolyte solutions so that the water will break down to produce positive and negative ions. Because the water in the experiment has been mixed with detergent material, this water becomes conductive. Electrical conductance is a measure of electrical conductivity, usually expressed in mhos [?]. Some kinds of electrolyte compounds found in detergents include sodium sulfate and sodium chloride.

\section{RESEARCH METHOD}

\section{A. Research Flow Chart}

In the flowchart of the study several steps were tested to obtain the voltage and current, for the first stage was carried out the collection of equipment and materials needed then testing for some detergent waste in which $50 \mathrm{~g}$ of detergent was dissolved with $1200 \mathrm{ml}$ water which would produce currents and voltages.

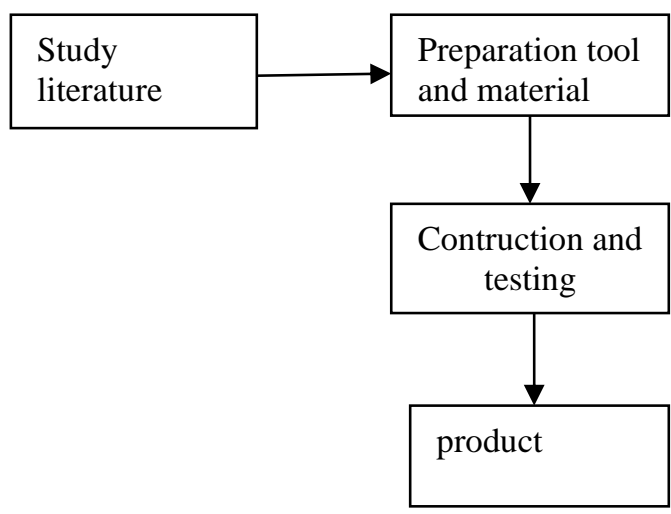

Fig. 2. Research Flowchart

\section{B. Implemenation Tools}

In the picture below it can be seen that the test by making a series of carbon and zinc as the anode and cathode while the liquid uses detergent waste water which results from the chemical reaction produces current and voltage.

\section{Electrolyte and Non-Electrolyte Solutions}

A liquid that can conduct an electric current is called an electrolyte solution, while a liquid that cannot conduct an electric current is called a non-electrolyte solution. The physical data of the solution being tested using an electrolyte test shows :

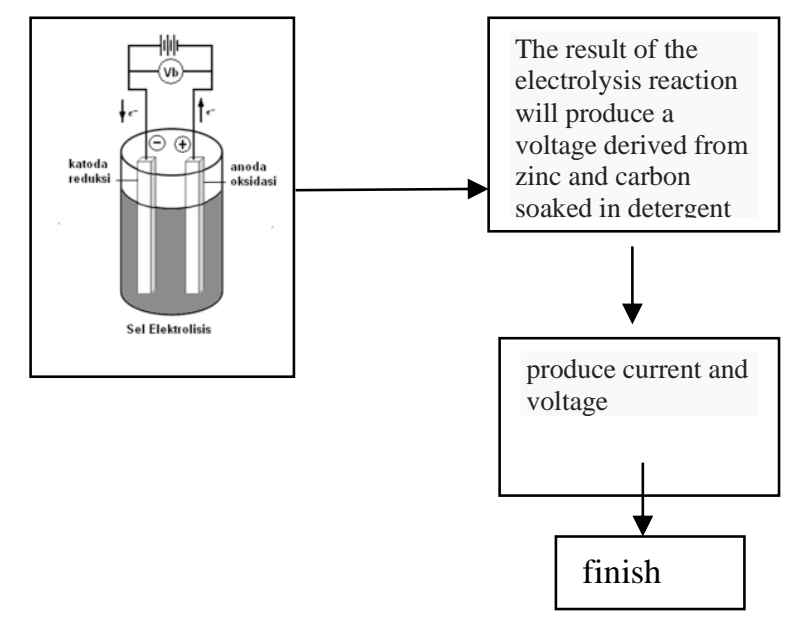

Fig. 3. Planning and Implementation Flow Chart

It can deliver electricity in the electrolyte solution due to the ions that can move freely. The more ions that move freely, the stronger the electrical conductivity. Strong electrolytes include all ionic compounds and some polar covalent compounds, i.e :

- Strong Acid : HClO4, HNO3, H2SO4, $\mathrm{HCl}, \mathrm{HBr}, \mathrm{HI}$

- Strong Alkali : $\mathrm{NaOH}, \mathrm{KOH}, \mathrm{Ca}(\mathrm{OH}) 2$, $\mathrm{Sr}(\mathrm{OH}) 2, \mathrm{Ba}(\mathrm{OH}) 2$

- Weak Acid : Formic acid $(\mathrm{HCOOH})$, Acetic Acid (CH3COOH), Hydrofluoric acid (HF), carbonic acid ( $\mathrm{H} 2 \mathrm{CO} 3)$

- Weak Alkali : Ammonium hydroxide $(\mathrm{NH} 4 \mathrm{OH})$, Aluminum hydroxide $(\mathrm{Al}(\mathrm{OH}) 3)$, Iron (III) hydroxide $(\mathrm{Fe}(\mathrm{OH}) 3)$

Table. 1. Electrolyte Solution

\begin{tabular}{|l|l|l|}
\hline $\begin{array}{l}\text { Non Electrolyte } \\
\text { Solution }\end{array}$ & $\begin{array}{l}\text { Weak Electrolyte } \\
\text { Solution }\end{array}$ & $\begin{array}{l}\text { Strong } \\
\text { Electrolyte } \\
\text { Solution }\end{array}$ \\
\hline $\begin{array}{l}\text { The Electrode off } \\
\text { lights have no } \\
\text { bubbles }\end{array}$ & $\begin{array}{l}\text { Dim / off light } \\
\text { Electrodes have little } \\
\text { bubbles }\end{array}$ & $\begin{array}{l}\text { Bright } \\
\text { lights } \\
\text { Electrodes } \\
\text { have a lot } \\
\text { of bubbles }\end{array}$ \\
\hline
\end{tabular}

\section{Molarity of Sodium Sulphate and Sodium Chloride Solution}

Molarity is used to show the number of moles of solute in each liter of solution [6]. 
JAREE-Journal on Advance Research in Electrical Engineering Volume3, Number 2, October 2019

$$
\begin{gathered}
M=\frac{\text { mol of solute }}{\text { liter of solution }}=\frac{n}{v} \\
M=\frac{1000}{v} \times n \\
M=\frac{g r a m}{M r} \times \frac{1000}{v}
\end{gathered}
$$

\begin{tabular}{|c|l|l|}
\hline 2. & Carbon & 1 \\
\hline 3. & Detergent & 1 \\
\hline 4. & AVO METER & 1 \\
\hline 5. & GLASS & 1 \\
\hline 6. & STIRRER & 1 \\
\hline 7. & DIGITAL WEIGHT & 1 \\
\hline
\end{tabular}

From the tools and materials above, experiments were conducted with 3 types of detergents. In the first experiment we tried by dissolving $100 \mathrm{ml}$ of water and $0.5 \mathrm{gr}$ of detergent in each brand in a measuring cup, then we stirred evenly with a glass stirrer. The next step is to dip the tip of the electrode. The electrodes we use are Zinc and Carbon, zinc as the anode pole and carbon as the cathode pole. Next we measured the voltage and current using the AVO meter as a measuring device. From the results of measurements it gets the following data

Table. 3. Detergent List

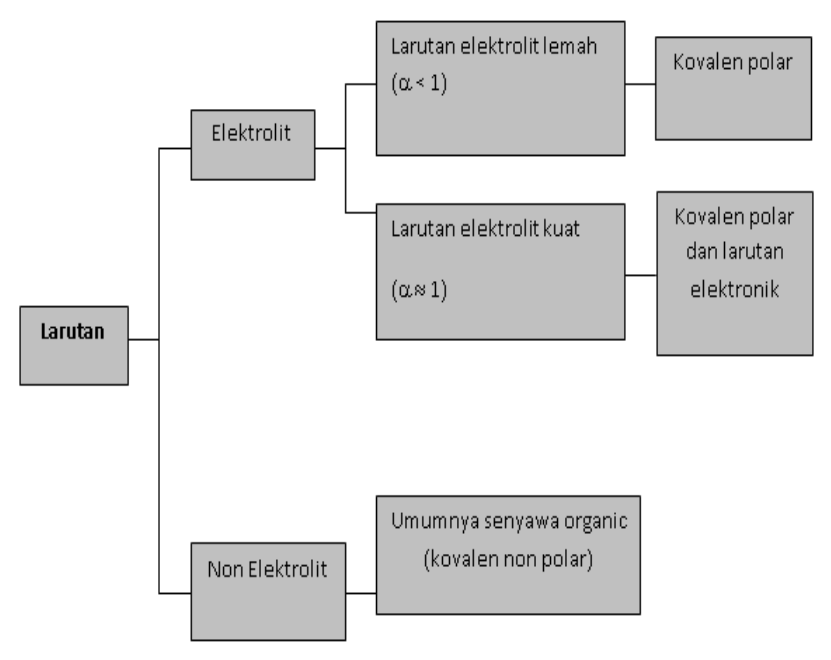

Fig. 4. Electrolyte and Non-electrolyte Solution

\section{TESTING}

\section{A. Experiment Preparation}

At this stage the tools and materials needed to carry out the testing are needed. This is necessary to plan what activities we will do in order to help realize Indonesian people to save energy by converting detergent wastewater into renewable energy.

\section{B. Experimenting}

At this stage conducted an experiment on 3 types of detergents that are widely used for washing clothes. Of course in a study requires the following tools and materials:

Table. 2. List of Research Tools

\begin{tabular}{|c|l|l|}
\hline NO & Tools & Quantity \\
\hline 1. & Zinc & 1 \\
\hline
\end{tabular}

\begin{tabular}{|l|l|l|l|l|}
\hline NO. & $\begin{array}{l}\text { Detergent } \\
\text { Brand }\end{array}$ & Quantity (gram) & voltage & current \\
\hline 1. & RINSO & 0,5 & $1 \mathrm{~V}$ & $2 \mathrm{~mA}$ \\
\hline 2. & DAIA & 0,5 & $0,7 \mathrm{~V}$ & $\begin{array}{l}0,56 \\
\mathrm{~mA}\end{array}$ \\
\hline 3. & SOKLIN & 0,5 & $0,8 \mathrm{~V}$ & $1 \mathrm{~mA}$ \\
\hline
\end{tabular}

Regarding the above data, we conclude that the Rinso detergent brand has the highest voltage and current compared to other detergents. Certainly in a prototype requires tools and materials. Use the following tools and materials:

Table. 4. List of Materials Electrolyte Solution

\begin{tabular}{|c|l|l|}
\hline NO & Tools & Quantity \\
\hline 1. & $\begin{array}{l}\text { Carbon Electrode From } \\
\text { battery }\end{array}$ & 6 \\
\hline 2. & Zinc from bateray & 6 \\
\hline 3. & Combination tank & 1 \\
\hline 4. & scissors & 1 \\
\hline 5. & Digital weight & 1 \\
\hline 6. & Avo & 1 \\
\hline NO & Tools & Quantity \\
\hline 7. & Cable & 4 \\
\hline 8. & LED & Plastic Container \\
\hline 9. & & 1 \\
\hline
\end{tabular}




\begin{tabular}{|c|l|l|}
\hline 10. & Cutter & 1 \\
\hline 11. & Waste detergent & $100 \mathrm{ml}$ \\
\hline 12. & Screwdriver & 1 \\
\hline
\end{tabular}

The random step of the test is $1200 \mathrm{ml}$ of total water mixed with a detergent of 50 grams, which will produce a voltage of $0.547 \mathrm{v}$, while a current of $0.06 \mathrm{~mA}$ trials with a glass size with $120 \mathrm{ml}$ wastewater

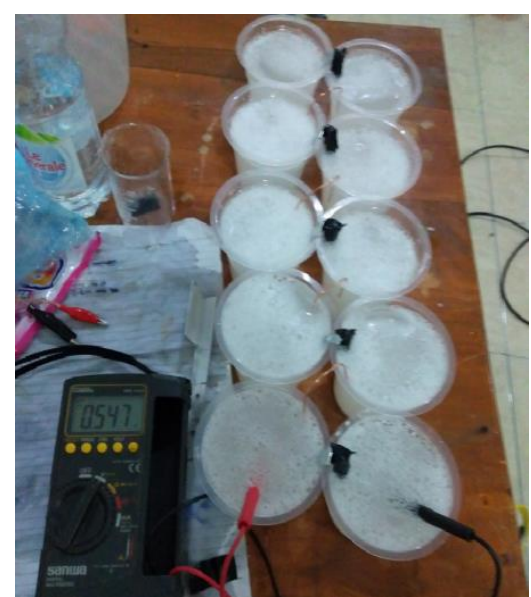

Fig. 5. Experiment on Detergent Solution

Experiment by looking at the concentration in the waste solution by calculating the Molarity value of $\mathrm{Naso} 4$ and $\mathrm{NaCl}$ in the detergent waste solution, $\mathrm{Mr} \mathrm{Na} \mathrm{So} 4=119, \mathrm{Mr} \mathrm{NaCl}$ $=58.5$

Table. 5. Molarity of $\mathrm{NaSO}_{4}$
\begin{tabular}{|l|l|l|l|l|l|}
\hline NO & $\begin{array}{l}\text { Detergent } \\
\text { Brand }\end{array}$ & $\begin{array}{l}\text { quantit } \\
\text { (gram) }\end{array}$ & $\begin{array}{l}\text { Volu } \\
\text { me } \\
(1)\end{array}$ & mol & $\begin{array}{l}\text { molarit } \\
\text { y }\end{array}$ \\
\hline 1. & RINSO & 0,5 & 0,25 & 0,004 & 16 \\
\hline 2. & DAIA & 0,5 & 0,5 & 0,004 & 8 \\
\hline 3. & SOKLIN & 0,5 & 1 & 0,004 & 4 \\
\hline
\end{tabular}

Table. 6. Molarity of $\mathrm{NaCl}$

\begin{tabular}{|l|l|l|l|l|l|}
\hline NO. & $\begin{array}{l}\text { Detergent } \\
\text { Brand }\end{array}$ & $\begin{array}{l}\text { quantit } \\
\text { y } \\
\text { (gram) }\end{array}$ & $\begin{array}{l}\text { Volum } \\
\mathrm{e} \\
(1)\end{array}$ & mol & $\begin{array}{l}\text { molar } \\
\text { ity }\end{array}$ \\
\hline 1. & RINSO & 0,5 & 0,25 & 0,008 & 32 \\
\hline 2. & DAIA & 0,5 & 0,5 & 0,008 & 16 \\
\hline 3. & SOKLIN & 0,5 & 1 & 0,008 & 8 \\
\hline
\end{tabular}

\section{CONCLUSION}

The greater the molarity value of an electrolyte in a detergent waste solution, it will be able to produce electric currents and voltages. From several experiments conducted for 3 detergents with several conditions, that is seen in the amount of mass with a volume of $120 \mathrm{ml}$ water produces a voltage of 1 volt with a current of $2 \mathrm{~mA}$ This is for detergent Rinso, for DAIA detergents it produces a voltage of 0.7 and a current of $0.56 \mathrm{~mA}$, and the experiment tested for SOKLIN produces a voltage of 0.8 volts with a large current of $1 \mathrm{~mA}$ while testing conducted randomly with a volume of $1200 \mathrm{ml}$ of water produces a voltage of $0.547 \mathrm{~V}$ with a current of 0.006 $\mathrm{mA}$ this proves that detergent waste can be utilized as renewable energy although it still requires further research but this can ease the burden on the community to pay for electricity from PLN and in the subsequent development independent power plants are built in each house so that the community can save electricity

\section{ACKNOWLEDGMENT}

For further researchers, it is better to add an electrolyte solution derived from liquid strong acids or strong bases so that they can react into a solution of detergent water, in order to get a large current and voltage value and are more stable in producing electricity.

\section{REFERENCES}

[1] M.P,M.Sc adelia desi kurniawati STP, larutan dan konsentrasi. malang, indonesia.

[2] M.Si dan Drs. Sunarto, M.Si Drs. Agus Salim, "REAKSI ELEKTROKIMIA," FMIPA UNY, 2001.

[3] M.Si. Drs. Iqmal Tahir, "ELEKTROKIMIA," agustus 2016.

[4] harley, "sel volta," 2009.

[5] labelelektronika.com. http://eprints.polsri.ac.id/4613/8/FILE\%20VIII.pdf.

[6] panjaitan, "laju pertumbuhan konsumsi deterjen diiindonesia," 2002.

[7] R. M. Mohamed, A. A. Al-Gheethi1, and J. Noramira,"Effect of detergents from laundry greywater on soil properties: a preliminary study", Tun Hussein. Johor. January 2018.

[8] J. R. Fischer, D. B. Brookew, and M. E. Andersow "Electrical Conductance of Various Detergent Ingredients in Milk-Water Solutions", Missouri. Columbia. Vol 56. No 11. 1405-1411.

[9] Michael A. Lewis, "The Effects of Mixtures and Other Environmental Modifying Factors on The Toxicities of Surfactants to Freshwater and Marine Life", US EPA, Sabine Island, Vol. 26, No. 8, pp. 1013-1023, February 1992.

10 Abulude, F. O, Fagbayide S.D and Olubayode, "Assessment of Physicochemical Properties of Soaps, Detergents and Water Samples Originated From Nigeria”, Federal Polytechnic. Ilaro. Ogun State, July 2017.

11 Ehilen, O.E., Obadoni, and B.O., Imade, "The Effect of Detergents on the Germination and Growth of Amaranthus hybridus L. and Solanum lycopersicon L", Nigerrian Annals of Natural Science, Vol 16(1) 2017 (pp 100 -108) 2019 